Correspondence Bharat K. C. Patel b.patel@griffith.edu.au

\section{Fervidicola ferrireducens gen. nov., sp. nov., a thermophilic anaerobic bacterium from geothermal waters of the Great Artesian Basin, Australia}

\author{
Christopher D. Ogg and Bharat K. C. Patel
}

Microbial Gene Research and Resources Facility, School of Biomolecular and Physical Sciences, Griffith University, Brisbane, OLD 4111, Australia

\begin{abstract}
A strictly anaerobic, thermophilic bacterium, designated strain $\mathrm{Y}_{170^{\top}}$, was isolated from a microbial mat colonizing thermal waters of a run-off channel created by the free-flowing waters of a Great Artesian Basin (GAB) bore well (New Lorne bore; registered number 17263). Cells of strain $\mathrm{Y}_{170^{\top}}$ were slightly curved rods $(1.2-12 \times 0.8-1.1 \mu \mathrm{m})$ and stained Gram-negative. The strain grew optimally in tryptone-yeast extract-glucose medium at $70{ }^{\circ} \mathrm{C}$ (temperature range for growth was $55-80^{\circ} \mathrm{C}$ ) and $\mathrm{pH} 7(\mathrm{pH}$ range for growth was $5-9)$. Strain $\mathrm{Y}_{170^{\top}}$ grew poorly on yeast extract as a sole carbon source, but not on tryptone (0.2\%). Yeast extract could not be replaced by tryptone and was obligately required for growth on tryptone, peptone, glucose, fructose, galactose, cellobiose, mannose, sucrose, xylose, mannitol, formate, pyruvate, Casamino acids and threonine. No growth was observed on arabinose, lactose, maltose, raffinose, chitin, xylan, pectin, starch, acetate, benzoate, lactate, propionate, succinate, myo-inositol, ethanol, glycerol, amyl media, aspartate, leucine, glutamate, alanine, arginine, serine and glycine. End products detected from glucose fermentation were acetate, ethanol and presumably $\mathrm{CO}_{2}$ and $\mathrm{H}_{2}$. Iron(III), manganese(IV), thiosulfate and elemental sulfur, but not sulfate, sulfite, nitrate or nitrite, were used as electron acceptors in the presence of $0.2 \%$ yeast extract. Iron(III) in the form of amorphous $\mathrm{Fe}$ (III) oxhydroxide and $\mathrm{Fe}$ (III) citrate was also reduced in the presence of tryptone, peptone and Casamino acids, but not with chitin, xylan, pectin, formate, starch, pyruvate, acetate, benzoate, threonine, lactate, propionate, succinate, inositol, ethanol, glycerol, mannitol, aspartate, leucine, glutamate, alanine, arginine, serine or glycine. Strain $\mathrm{Y}_{170^{\top}}$ was not able to utilize molecular hydrogen and/or carbon dioxide in the presence or absence of iron(III).

Chloramphenicol, streptomycin, tetracycline, penicillin and ampicillin and $\mathrm{NaCl}$ concentrations greater than $2 \%$ inhibited growth. The $\mathrm{G}+\mathrm{C}$ content of the DNA was $48 \pm 1 \mathrm{~mol} \%$ [SD $(n=3)$; $T_{\mathrm{m}}$ ]. 16S rRNA gene sequence analysis indicated that strain $\mathrm{Y}_{170^{\top}}$ is a member of the family Syntrophomonadaceae, class Clostridia, phylum Firmicutes and was most closely related to members of the genus Thermosediminibacter (mean similarity of $93.6 \%$ ). On the basis of the $16 \mathrm{~S}$ rRNA gene sequence comparisons and physiological characteristics, strain $\mathrm{Y}_{170^{\top}}$ is considered to represent a novel species of a new genus, for which the name Fervidicola ferrireducens gen. nov., sp. nov. is proposed. The type strain is $\mathrm{Y}_{170^{\top}}\left(=\mathrm{KCTC} 5610^{\top}=\mathrm{JCM} 15106^{\top}=\mathrm{DSM}\right.$ $\left.21121^{\top}\right)$.
\end{abstract}

The Great Artesian Basin (GAB) of Australia underlies approximately one-fifth of the Australian continent, covering an area of $1.7 \times 10^{6} \mathrm{~km}^{2}$ with a water-storage capacity of $8.7 \times 10^{12} \mathrm{~m}^{3}$ (Habermahl, 1980), and is considered to be the world's largest geothermal subsurface aquifer. The $G A B$ provides a vital water resource for rural semiarid communities and contains the largest onshore oil

Abbreviation: GAB, Great Artesian Basin.

The GenBank/EMBL/DDBJ accession number for the 16S rRNA gene sequence of strain $\mathrm{Y}_{170^{\top}}$ is EU443728. and gas reserves in Australia. It is composed of alternating layers of water-bearing permeable sandstone aquifers and non-water-bearing impermeable mudstones and siltstones, which have a major influence on the chemical composition of GAB groundwaters, which can be bicarbonate-, chloride-, sulfate- or iron-rich. The GAB is estimated to be between 100 and 250 million years old, but contains groundwater estimated to be 2 million years old. The GAB is recharged at the eastern margin of the basin by rainwater and, after traversing some $1200 \mathrm{~km}$ underground at an estimated flow rate of $1-5 \mathrm{~m} \mathrm{year}^{-1}$, is discharged in 
central Australia as mound springs. In addition, approximately 5000 man-made artesian bore wells have tapped the $\mathrm{GAB}$ as a much needed water resource for outback communities. The GAB water is heated due to its great depth (up to $3000 \mathrm{~m}$ ) and the source temperatures of freeflowing bores can be as high as $100{ }^{\circ} \mathrm{C}$, depending on bore depth. The combination of the unique chemical composition, varying temperatures and slow flow rate of the $G A B$ groundwaters makes the $\mathrm{GAB}$ a conducive habitat for microbial growth and a range of thermophilic and mesophilic micro-organisms have been isolated and characterized from the GAB waters, including sulfatereducers (Love et al., 1993; Redburn \& Patel, 1994), carbohydrate-fermenters (Andrews \& Patel, 1996), strict aerobes (Kanso \& Patel, 2003; Spanevello et al., 2002) and $\mathrm{Fe}(\mathrm{III})$-reducers (Kanso et al., 2002). Recently, we have focused our studies on four visible and thriving macroscopic microbial mats spatially distributed at specific temperatures along the temperature gradient of the freeflowing bore water run-off channels formed by the New Lorne bore (registered bore number 17263). Cultureindependent analyses of four microbial mats from the New Lorne bore run-off channel indicated that members of the genus Thermus dominated the $75{ }^{\circ} \mathrm{C}$ grey mat, Meiothermus dominated the $66{ }^{\circ} \mathrm{C}$ red mat, Cyanobacteria dominated the $57{ }^{\circ} \mathrm{C}$ green mat and Deinococci-Thermus and Alphaproteobacteria dominated the $52{ }^{\circ} \mathrm{C}$ brown mat, and that the phylogenetic diversity increased as the water temperature decreased and species spanning the domain Bacteria, including numerous uncultured organisms, were present (Spanevello, 2001). The GAB is very rich in reduced iron and, as $\mathrm{Fe}(\mathrm{III})$-reducing micro-organisms play important roles in the cycling of metals and organic matter in deep subsurface environments and influence water quality and taste (Lovley, 1997), have potential applications in bioremediation, biomineral leaching and energy generation processes, are of immense evolutionary significance as they have been linked to the Last Common Ancestor (Vargas et al., 1998) and together with sulfatereducers may be responsible for bore metal corrosion, leading to bore failure causing significant water wastage and hardship to outback communities, we have initiated studies on iron-reducers of the GAB. In this report, we describe a strictly anaerobic, thermophilic, Fe(III)-reducer, designated strain $\mathrm{Y}_{170^{\mathrm{T}}}$, isolated from a grey mat colonizing the run-off channel of the New Lorne bore at $75{ }^{\circ} \mathrm{C}$. Strain $\mathrm{Y} 170^{\mathrm{T}}$ is considered to represent a novel species of a novel genus, Fervidicola ferrireducens gen. nov., sp. nov.

The grey microbial mat used in this study was collected from the run-off channel of the New Lorne bore situated near Blackall, some $1000 \mathrm{~km}$ north-west of Brisbane, QLD, Australia ( $\left.24^{\circ} 54^{\prime} 48^{\prime \prime} \mathrm{S} 145^{\circ} 08^{\prime} 18^{\prime \prime} \mathrm{E}\right)$. The bore well was drilled initially in 1966 and has a depth of $1613 \mathrm{~m}$. The temperature of the free-flowing water (flow rate of $7.6 \mathrm{~s}^{-1}$ ) at the bore head was $88{ }^{\circ} \mathrm{C}$ and the $\mathrm{pH}$ was 8.5 , and the temperature at the site where the grey mat was collected was $75{ }^{\circ} \mathrm{C}$. Iron concentrations of the free-flowing water were found to be $0.01 \mathrm{mg} \mathrm{l^{-1 }}$. The mats were collected in sterile glass vessels and the vessels were filled to the brim with water from the run-off channel, capped, transported to the laboratory and stored at $4{ }^{\circ} \mathrm{C}$ until used. The microbial mats have been described previously (Spanevello et al., 2002).

Enrichment and isolation was performed in anaerobic PL medium, with the addition of $2 \mathrm{~g}$ yeast extract $\mathrm{l}^{-1}$. The PL medium contained $\left(\mathrm{l}^{-1}\right.$ deionized water): $1 \mathrm{~g} \mathrm{NH}_{4} \mathrm{Cl}, 0.6 \mathrm{~g}$ $\mathrm{K}_{2} \mathrm{HPO}_{4}, \quad 0.3 \mathrm{~g} \quad \mathrm{KH}_{2} \mathrm{PO}_{4}, \quad 0.1 \mathrm{~g} \quad \mathrm{MgCl}_{2} .6 \mathrm{H}_{2} \mathrm{O}, \quad 0.1 \mathrm{~g}$ $\mathrm{CaCl}_{2} \cdot 2 \mathrm{H}_{2} \mathrm{O}, 1.0 \mathrm{~g} \mathrm{NaCl}, 1 \mathrm{ml}$ vitamin solution (Wolin et al., 1963), $1 \mathrm{ml}$ trace-element solution (Zeikus et al., 1979), $12.0 \mathrm{~g}$ HEPES, $0.2 \mathrm{~g}$ yeast extract and $3.0 \mathrm{~g}$ amorphous $\mathrm{Fe}(\mathrm{III})$ oxhydroxide (Lovley \& Phillips, 1986). The $\mathrm{pH}$ of the medium was adjusted to 7.2 with $1 \mathrm{M} \mathrm{NaOH}$ and $1 \mathrm{M} \mathrm{HCl}$ and the medium was heated for $10 \mathrm{~min}$ in an autoclave at $121{ }^{\circ} \mathrm{C}$ and $1-1.5 \mathrm{~kg} \mathrm{~cm}^{-2}$ pressure. The medium was then cooled under a stream of oxygen-free nitrogen gas, dispensed into Hungate tubes under oxygen-free nitrogen gas and sterilized for $30 \mathrm{~min}$ at $121{ }^{\circ} \mathrm{C}$ and at a pressure of $1-1.5 \mathrm{~kg} \mathrm{~cm}^{-2}$. Enrichment cultures were initiated by injecting $500 \mu \mathrm{l}$ of mat sample suspension into the PL medium $(9.5 \mathrm{ml})$ followed by incubation at $70{ }^{\circ} \mathrm{C}$ for 3 days. The enrichment culture was serially diluted and incubated again under the same conditions. The tube containing the highest serial dilution was selected and the procedure was repeated at least three times before a bacterium, designated $\mathrm{Y} 170^{\mathrm{T}}$, was isolated and deemed to be a pure culture. Culture purity was confirmed by using $16 \mathrm{~S}$ rRNA gene sequencing and the pure culture was stored in a glycerol-PL medium $(50: 50)$ mixture at $-20{ }^{\circ} \mathrm{C}$.

Cell morphology was determined by using phase-contrast microscopy and electron microscopy (Kanso \& Patel, 2003). The cells of strain $\mathrm{Y}_{170^{\mathrm{T}}}$ were peritrichously flagellated, slightly curved rods $(1.2-12 \times 0.8-1.1 \mu \mathrm{m})$ that occurred singly, in pairs and in chains. Spores were not observed for cultures that had been grown under suboptimal conditions (different $\mathrm{pH}$ and temperatures), and on glucose and xylose. In addition, cultures heated at $95{ }^{\circ} \mathrm{C}$ for 20 min failed to grow in tryptone-yeast extractglucose (TYEG) medium after subculture (Patel et al., $1985 \mathrm{a}, \mathrm{b})$, suggesting the absence of heat resistant bodies such as spores. Cells of strain $\mathrm{Y} 170^{\mathrm{T}}$ stained Gram-negative and electron micrographs of thin sections confirmed a Gram-negative cell-wall ultrastructure consisting of an electron-dense layer (inner wall layer) adjacent to the cell membrane and an electron light layer consisting of regular protein subunits (outer wall layer) (Fig. 1).

Unless otherwise indicated, all growth experiments were conducted at least twice and cultures were subcultured at least once in the same medium prior to the conduct of the experiment. Growth of strain $\mathrm{Y}_{170^{\mathrm{T}}}$ was tested in anaerobic TYEG medium that contained low phosphatebuffered salts (LPBS) supplemented with $0.2 \%$ each of 
(a)

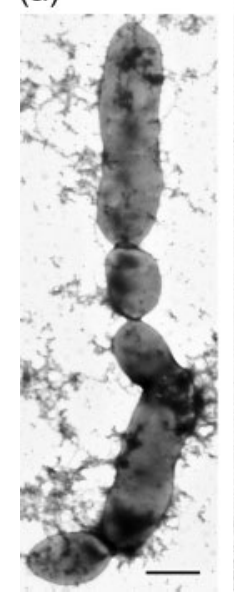

(b)

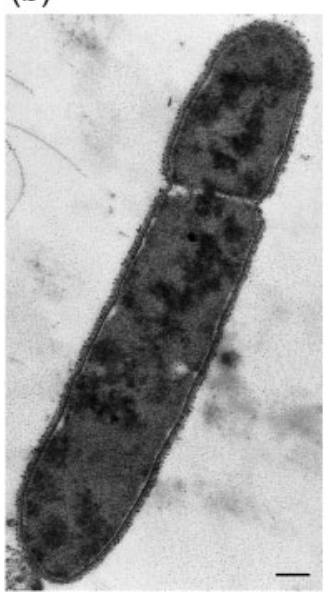

(c)

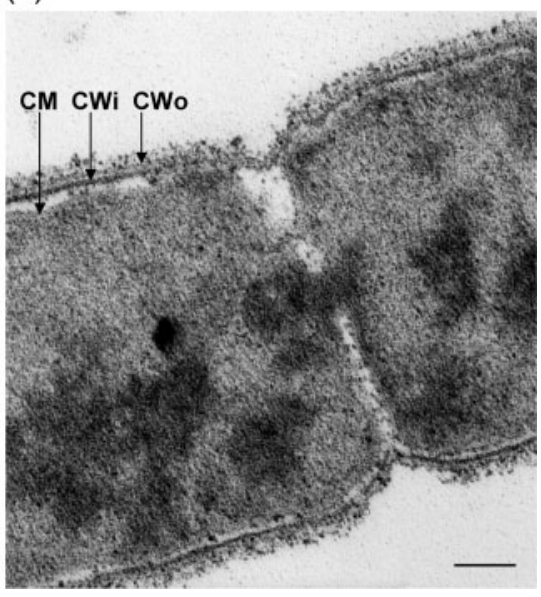

Fig. 1. (a) Electron micrograph of negatively stained cells of strain $\mathrm{Y}_{170^{\top}}$ showing cell morphology and irregular cell division. Bar, $1 \mu \mathrm{m}$. (b) Transmission electron micrograph of thin sections of cells of strain $\mathrm{Y} 170^{\top}$. Bar, $200 \mathrm{~nm}$. (c) Enlargement of (a) showing cellwall ultrastructure, showing the presence of a cytoplasmic membrane (CM), an electrondense cell-wall layer adjacent to the membrane $(\mathrm{CWi})$ and an electron-light outer cell-wall layer composed of regular subunits (CWo). Bar, $100 \mathrm{~nm}$. tryptone, yeast extract and glucose at temperatures and $\mathrm{pH}$ ranging from 26 to $85{ }^{\circ} \mathrm{C}$ and 5.0 to 9.5, respectively. Growth was measured at $580 \mathrm{~nm}$ by inserting Hungate tubes directly into a modified cuvette holder of a Novaspec LKB spectrophotometer (Pharmacia-Biotech). Strain $\mathrm{Y}_{170}{ }^{\mathrm{T}}$ grew optimally in TYEG medium at $70{ }^{\circ} \mathrm{C}$ (temperature range for growth of $55-80{ }^{\circ} \mathrm{C}$ ) and a $\mathrm{pH}$ of 7 ( $\mathrm{pH}$ range for growth of 6-9), with a generation time of $4.6 \mathrm{~h}$. Unless indicated otherwise, all subsequent growth experiments were conducted under these conditions.

Strain $\mathrm{Y}_{170^{\mathrm{T}}}$ was tested for its ability to use LPBS supplemented with $0.2 \%$ tryptone (medium T), $0.2 \%$ yeast extract (medium YE) or $0.2 \%$ each of tryptone and yeast extract (medium TYE) as carbon sources. No growth was observed in medium $\mathrm{T}$ and growth of approximately 15 and $28 \%$ was observed in medium YE and medium TYE, respectively, compared with growth (100\%) in TYEG medium $(100 \%$ growth $=$ OD $580 \mathrm{~nm}$ of 0.4$)$. Strain $\mathrm{Y}_{170^{\mathrm{T}}}$ did not grow on $0.2 \%$ glucose (medium $G$ ) as the sole carbon source, which was fermented in the presence of $0.2 \%$ tryptone (TG medium) reaching an OD $580 \mathrm{~nm}$ of 0.2 (50\% growth) and in the presence of $0.2 \%$ yeast extract (YEG medium) reaching an OD $580 \mathrm{~nm}$ of 0.4 (100\% growth).

Substrate utilization tests were performed in the presence of $0.2 \%$ yeast extract. Soluble substrates were added to sterile YE medium from sterile anaerobic stock solutions to a final concentration of $0.2 \%$. Insoluble substrates were weighed directly into Hungate tubes, YE medium was dispensed and the medium was sterilized. Growth was measured at $580 \mathrm{~nm}$ three times a day until the culture reached stationary phase. Growth was considered as positive when the turbidity of the culture was at least $20 \%$ higher in YE medium containing substrates, compared with YE medium that lacked the substrates. Strain $\mathrm{Y} 170^{\mathrm{T}}$ utilized tryptone, peptone, glucose, fructose, galactose, cellobiose, mannose, sucrose, xylose, mannitol, formate, pyruvate, Casamino acids and threonine, but not arabinose, lactose, maltose, raffinose, chitin, xylan, pectin, starch, acetate, benzoate, lactate, propionate, succinate, myo-inositol, ethanol, glycerol, amyl media, aspartate, leucine, glutamate, alanine, arginine, serine or glycine.

End products from glucose fermentation in TYEG medium were determined as described previously (Chrisotomos et al., 1996), with the exception that the oven and injector temperatures were 200 and $215^{\circ} \mathrm{C}$, respectively. End products detected from glucose fermentation were ethanol, acetate and presumably $\mathrm{CO}_{2}$ and $\mathrm{H}_{2}$.

To determine the substrates used by strain $\mathrm{Y} 170^{\mathrm{T}}$ with reduction of $\mathrm{Fe}(\mathrm{III})$, substrates were added to PL medium, supplemented with $2 \mathrm{~g}$ ammonium $\mathrm{Fe}$ (III) citrate $\mathrm{l}^{-1}$ instead of amorphous $\mathrm{Fe}$ (III) oxide. The cultures were incubated for 8 days at $70{ }^{\circ} \mathrm{C}$ and $\mathrm{Fe}$ (III) reduction was inferred when a transformation of the reddish-brown colour of the $\mathrm{Fe}(\mathrm{III})$ to a dark precipitate $[\mathrm{Fe}(\mathrm{II})]$ and a clearing of the media were observed. Fe(III) reduction was confirmed by measuring $\mathrm{Fe}(\mathrm{II})$ accumulation using the ferozine method (Sorensen, 1982). A $0.1 \mathrm{ml}$ sample was mixed with $3 \mathrm{ml}$ ferozine reagent, and after $1 \mathrm{~min}$ the absorbance at $562 \mathrm{~nm}$ was determined. A culture in PL media without substrates was used as a negative control and a culture in PL media supplemented with $2 \mathrm{~g}$ yeast extract $1^{-1}$ was used as a positive control. Under sterile conditions, $\mathrm{Fe}$ (III) reduction can occur spontaneously at elevated temperatures in the presence of carbohydrates (Zavarzina et al., 2002) and hence carbohydrates were not tested. Fe(III) was reduced in the presence of yeast extract, tryptone, peptone and Casamino acids, but not formate, acetate, propionate, pyruvate, lactate, succinate, ethanol, glycerol, benzoate, aspartate, leucine, glutamate, threonine, alanine, arginine, serine or glycine. Given that $\mathrm{Fe}(\mathrm{III})$ is reduced in the presence of substrates that could also be utilized fermentatively, an investigation to determine whether energy is conserved to support growth from the reduction of $\mathrm{Fe}$ (III) to $\mathrm{Fe}$ (II) was deemed to be impractical. 
The potential for molecular hydrogen or carbon dioxide to serve as an electron donor in the presence and absence of $\mathrm{Fe}(\mathrm{III})$ was studied using $60 \mathrm{ml}$ serum bottles containing $10 \mathrm{ml} \mathrm{PL}$ medium with $\mathrm{H}_{2}(100,10$ and $5 \%, \mathrm{v} / \mathrm{v}) / \mathrm{CO}_{2}$ (balance) or $\mathrm{CO}_{2}(100 \%)$ as the gas phase, and $10 \mathrm{ml}$ yeast extract $(0.02 \%)$-supplemented LPBS media with $\mathrm{CO}_{2}$ or $\mathrm{H}_{2}: \mathrm{CO}_{2}(80: 20)$ as the gas phase. Strain $\mathrm{Y}_{170^{\mathrm{T}}}$ did not reduce $\mathrm{Fe}(\mathrm{III})$ in the presence of $\mathrm{CO}_{2}(100 \%)$ or $\mathrm{H}_{2} / \mathrm{CO}_{2}$ $(100,10$ and $5 \%, \mathrm{v} / \mathrm{v})$ and did not grow with $\mathrm{CO}_{2}$ or $\mathrm{H}_{2}: \mathrm{CO}_{2}(80: 20)$.

Electron acceptor utilization tests for sodium thiosulfate $(20 \mathrm{mM})$, sodium sulfate $(20 \mathrm{mM})$, sodium sulfite (5 mM), elemental sulfur $(1 \%)$, sodium nitrate $(20 \mathrm{mM})$ and sodium nitrite $(5 \mathrm{mM})$ were determined in YE medium without the reductant $\mathrm{Na}_{2} \mathrm{~S}$. The reduction of sulfate, sulfite, elemental sulfur and thiosulfate was tested using the method of Ramamoorthy et al. (2006). $\mathrm{Fe}\left(\mathrm{NH}_{4}\right)_{2}\left(\mathrm{SO}_{4}\right)_{2}(0.5 \%)$ was added to culture tubes, which were scored positive for the reduction of oxidized sulfur compounds when a black FeS precipitate was formed. The reduction of nitrate and nitrite to nitrogen $\left(\mathrm{N}_{2}\right)$ was determined by using Durham tubes. Cultures were scored as positive when the gas collected in the Durham tube was greater than that found in control tubes without nitrate and nitrite. Reduction of nitrate to nitrite was determined using Nitrite Test kits as described by the manufacturer (Aqua One). The reduction of nitrate to ammonium was subsequently tested using the same solution with the addition of $1 \mathrm{mg}$ zinc powder (Merck). The strain was scored as positive for the reduction of nitrate to ammonium when no colour change occurred or negative for nitrate reduction when a pink colour change occurred. The reduction of nitrite to ammonium was tested using an Ammonia Test kit (Aqua One). Electron acceptor utilization tests for manganese(IV) were tested in PL medium in which amorphous $\mathrm{Fe}$ (III) oxyhydroxide was replaced with $2 \mathrm{~g} \mathrm{Mn}(\mathrm{IV}) \mathrm{l}^{-1}$ (Lovley \& Phillips, 1988). Mn(IV) reduction was inferred by a clearing of the media and was further confirmed using the leuco crystal violet manganese oxide detection technique (Spratt et al., 1994). $\mathrm{MnO}_{2}$ concentration was determined by mixing $0.2 \mathrm{ml}$ of the sample with $4 \mathrm{ml}$ leuco crystal violet reagent, which was diluted, and the absorbance at $562 \mathrm{~nm}$ was determined. Strain $\mathrm{Y} 170^{\mathrm{T}}$ was able to reduce $\mathrm{Mn}(\mathrm{IV})$, thiosulfate and elemental sulfur, but not sulfate, sulfite, nitrate or nitrite.

Strain $\mathrm{Y} 170^{\mathrm{T}}$ was unable to grow under aerobic conditions in medium D (Brock \& Freeze, 1969) or in aerobic YE medium.

Antibiotic sensitivity was determined in TYEG media to which was added antibiotics (from filter-sterilized stock solutions) to a final concentration of 10 and $100 \mu \mathrm{g} \mathrm{ml}^{-1}$. Growth inhibition for each antibiotic was calculated from final turbidity measurements of cultures that had been grown in antibiotic-free TYEG medium and was expressed as percentage inhibition. Growth of strain $\mathrm{Y}_{170^{\mathrm{T}}}$ was completely inhibited (100\% inhibition) in the presence of $10 \mu \mathrm{g} \mathrm{ml}^{-1}$ ampicillin, streptomycin, tetracycline or penicillin and $100 \mu \mathrm{g}$ chloramphenicol $\mathrm{ml}^{-1}$. Strain $\mathrm{Y}_{170^{\mathrm{T}}}$ was able to grow without $\mathrm{NaCl}$ or at concentrations less than $2 \%$.

To determine the mol\% DNA G $+\mathrm{C}$ content of strain $\mathrm{Y} 170^{\mathrm{T}}$, DNA extraction and genome amplification was performed using TempliPhi Amplification kits (Amersham Biosciences). An aliquot of $0.4 \mu \mathrm{l}$ pelleted exponentialphase cells that had been washed three times in sterile deionized $\mathrm{H}_{2} \mathrm{O}$ and incubated at $4-4.5 \mathrm{~min}$ at $95{ }^{\circ} \mathrm{C}$ to extract the DNA was used per TempliPhi reaction. DNA quality was assessed by using agarose gel electrophoresis and ethidium bromide staining followed by visualization under a UVP GDAS 1200 Gel Documentation Analysis System (UVP). The mol\% G +C content of the genomic DNA was determined by using the thermal denaturation method (Marmur \& Doty, 1962) with a Cintra20 spectrophotometer (GBC Scientific Equipment) as described by Spanevello et al. (2002) and was calculated to be $48 \pm 1 \mathrm{~mol} \%$ (SD; $n=3$ ).

Inorganic $\mathrm{Fe}(\mathrm{III})$ present in PL medium can interfere with genomic DNA extraction and PCR (Kashefi et al., 2003). Thioglycollic acid pre-treatment was used to reduce and precipitate $\mathrm{Fe}(\mathrm{III})$ prior to genomic DNA extraction. For this, $40 \mu \mathrm{l}$ thioglycollic acid was added to exponentialphase cultures in $35 \mathrm{ml}$ PL medium, mixed by inversion and allowed to settle for $5 \mathrm{~min}$. The supernatant was then centrifuged at 8000 r.p.m. at $4{ }^{\circ} \mathrm{C}$ for 15 min (Sigma $4 \mathrm{~K} 15)$. The pellet was collected and resuspended in $7.5 \mathrm{ml}$ TE buffer, and $10 \mu \mathrm{l}$ thioglycollic acid was added and mixed by gentle inversion. The mixture was allowed to settle and the supernatant was centrifuged as described above. The cell pellet was washed in $3.5 \mathrm{ml}$ TE buffer to remove traces of thioglycollic acid and resuspended in $460 \mu \mathrm{l}$ TE buffer. Genomic DNA was extracted from the pre-treated cell pellet using a modification of the method of Marmur (1961), in which achromopeptidase (final concentration, $0.3 \mathrm{mg} \mathrm{ml}^{-1}$ ) was used to improve cell lysis with lysozyme. The DNA was dissolved in $10 \mathrm{mM}$ Tris/ $\mathrm{HCl}$ $(\mathrm{pH}$ 8.0) and its quality was assessed by using agarose gel electrophoresis as described above. Aliquots of $2 \mu \mathrm{l}$ of the DNA were used as a template for amplification of the $16 \mathrm{~S}$ rRNA gene (Andrews \& Patel, 1996). The sequencing of the gene was performed essentially as described previously (Andrews \& Patel, 1996). The partial sequences that were generated were assembled using BioEdit v. 5.0.1 (Hall, 1999 ) and the consensus sequence of 1528 nucleotides was corrected manually for errors. The most closely related sequences in the GenBank (version 152) and the Ribosomal Database Project II (release 9.37) identified using BLAST (Altschul et al., 1997) and Sequence Match program (Cole et al., 2005) were extracted, aligned and manually adjusted according to the $16 \mathrm{~S}$ rRNA secondary structure using BioEdit. Nucleotide ambiguities were omitted and evolutionary distances were calculated by using the Jukes and Cantor option (Jukes \& Cantor, 1969) in TREECON (Van de 
Peer et al., 1997). Phylogenetic trees were constructed from evolutionary distances using the neighbour-joining method (Saitou \& Nei, 1987). Tree topology was re-examined by using the bootstrap method based on 1000 resamplings (Felsenstein, 1985).

16S rRNA gene sequence analysis indicated that strain $\mathrm{Y} 170^{\mathrm{T}}$ was related to members of the family Syntrophomonadaceae, class Clostridia, phylum Firmicutes, and was phylogenetically positioned between members of the genus Thermosediminibacter (mean sequence similarity, 93.5\%) and Thermovenabulum ferriorganovorum (91.9\%) (Fig. 2). All strains are motile, thermophilic organisms that grow optimally near neutral $\mathrm{pH}$ levels, vary greatly in cell length, require yeast extract for growth and utilize fructose, sucrose and xylose, reduce manganese(IV), thiosulfate and elemental sulfur but not sulfate and, with the exception of Thermovenabulum ferriorganovorum, exist in deep subsurface environments (Lee et al., 2005; Zavarzina et al., 2002). Phenotypic characteristics shared between strain $\mathrm{Y}_{170^{\mathrm{T}}}$ and Thermovenabulum ferriorganovorum, but not possessed by Thermosediminibacter species, Thermosediminibacter litoriperuensis and Thermosediminibacter oceani, such as Fe(III) reduction, a lower salinity growth range and the inability to utilize lactate, concur with the 16S rRNA gene sequence analysis that strain $\mathrm{Y} 170^{\mathrm{T}}$ represents a new genus that is intermediate between the genera Thermosediminibacter and Thermovenabulum. Similarly, strain $\mathrm{Y}_{170^{\mathrm{T}}}$ has various phenotypic characteristics in common with Thermosediminibacter species but not Thermovenabulum ferriorganovorum, including Gram-negative cell-wall structures, longer cell length, sensitivity to heat-shock, similar mol\% DNA $\mathrm{G}+\mathrm{C}$ content, the ability to utilize glucose, galactose and mannose, and the inability to form spores and reduce sulfite and nitrate as electron acceptors. In addition, strain $\mathrm{Y} 170^{\mathrm{T}}$ can be differentiated from members of the genus Thermosediminibacter by glucose fermentation end products, its higher DNA G + C content and its inability to utilize inositol (Table 1). Strain $\mathrm{Y} 170^{\mathrm{T}}$ can be differentiated from Thermosediminibacter litoriperuensis by its ability to utilize cellobiose, pyruvate and Casamino acids, but not acetate and from Thermosediminibacter oceani by its inability to utilize maltose. Strain $\mathrm{Y} 170^{\mathrm{T}}$ also differed from Thermovenabulum ferriorganovorum by its sensitivity to heat-shock and $100 \mu \mathrm{g}$ penicillin $\mathrm{ml}^{-1}$, higher $\mathrm{G}+\mathrm{C}$ DNA

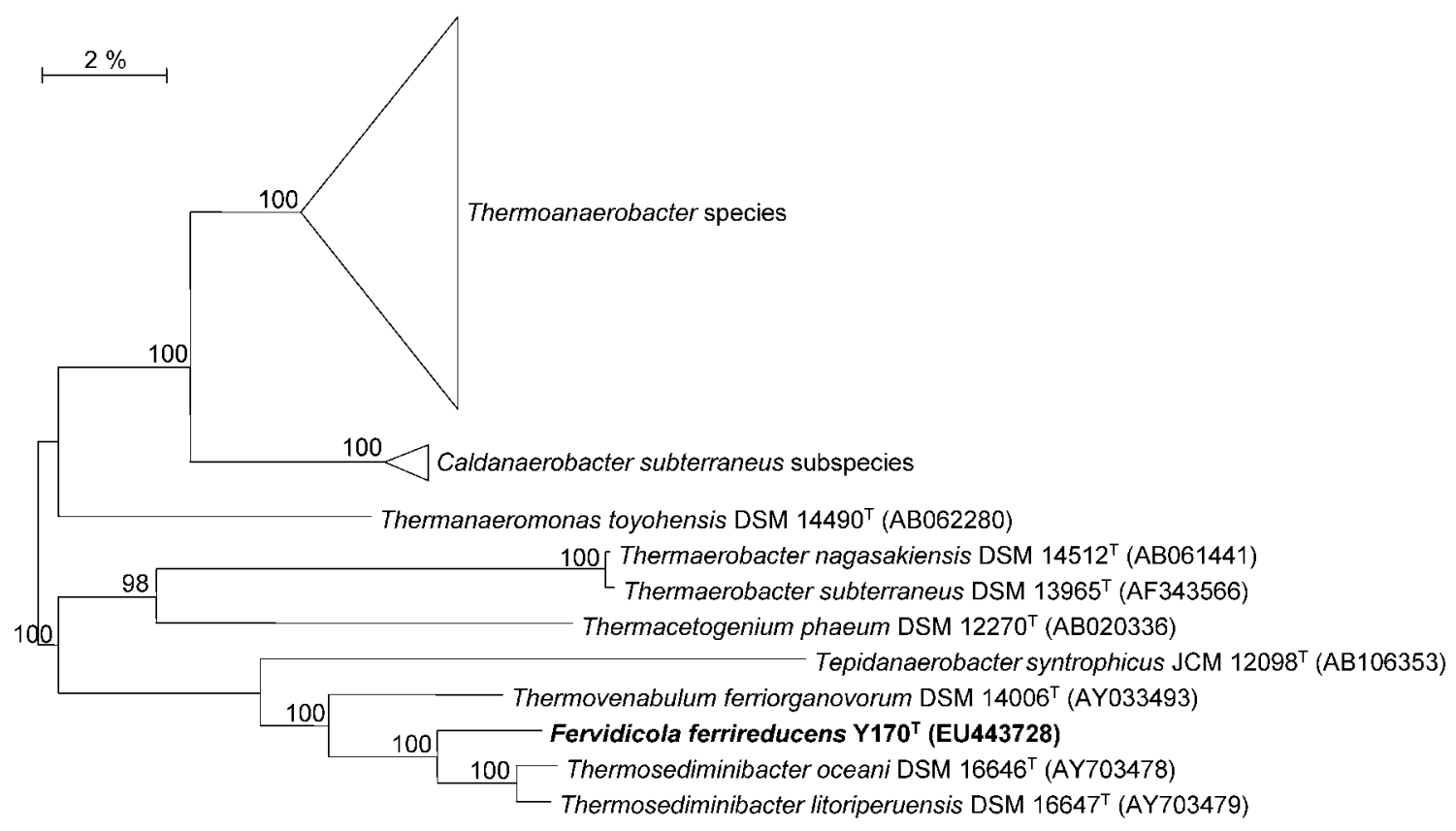

Fig. 2. Dendrogram showing the phylogenetic position of strain $Y 170^{\top}$ (Fervidicola ferrireducens gen. nov., sp. nov.) and its closest relatives. GenBank accession numbers are given in the parentheses. Clusters of members of the same genus or species are indicated by triangles and include: Thermoanaerobacter mathranii DSM $11426^{\top}$ (GenBank accession number Y11279), Thermoanaerobacter siderophilus DSM 12299 ${ }^{\top}$ (AF120479), Thermoanaerobacter italicus DSM 9252 ${ }^{\top}$ (AJ250846), Thermoanaerobacter acetoethylicus ATCC $33265^{\top}$ (X69336), Thermoanaerobacter wiegelii DSM 10319 ${ }^{\top}$ (X92513), Thermoanaerobacter kivui ATCC $33488^{\top}$ (L09160), Thermoanaerobacter thermohydrosulfuricus ATCC 35045 ${ }^{\top}$ (L09161), Thermoanaerobacter ethanolicus ATCC $31550^{\top}$ (L09162), Thermoanaerobacter brockii subsp. brockii DSM 1457 ${ }^{\top}$ (L09165), Thermoanaerobacter brockii subsp. finnii DSM $3389^{\top}$ (L09166) and Thermoanaerobacter thermocopriae JCM $7501^{\top}$ (L09167) for the genus Thermoanaerobacter, and Caldanaerobacter subterraneus subsp. tengcongensis JCM $11007^{\top}$ (AF209708) and Caldanaerobacter subterraneus subsp. yonseiensis DSM $13777^{\top}$ (AF212925) for the species Caldanaerobacter subterraneus. Bootstrap values $>95 \%$ are shown. Bar, 2 nucleotide changes per 100 nucleotides. 
Table 1. Selected characteristics of strain $Y 170^{\top}$ and closest relatives

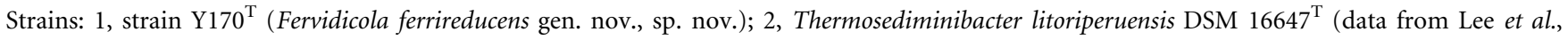
2005); 3, Thermosediminibacter oceani DSM $16646^{\mathrm{T}}$ (Lee et al., 2005); 4, Thermovenabulum ferriorganovorum DSM $14006^{\mathrm{T}}$ (Zavarzina et al., 2002). + , Positive; -, negative; ND, not determined.

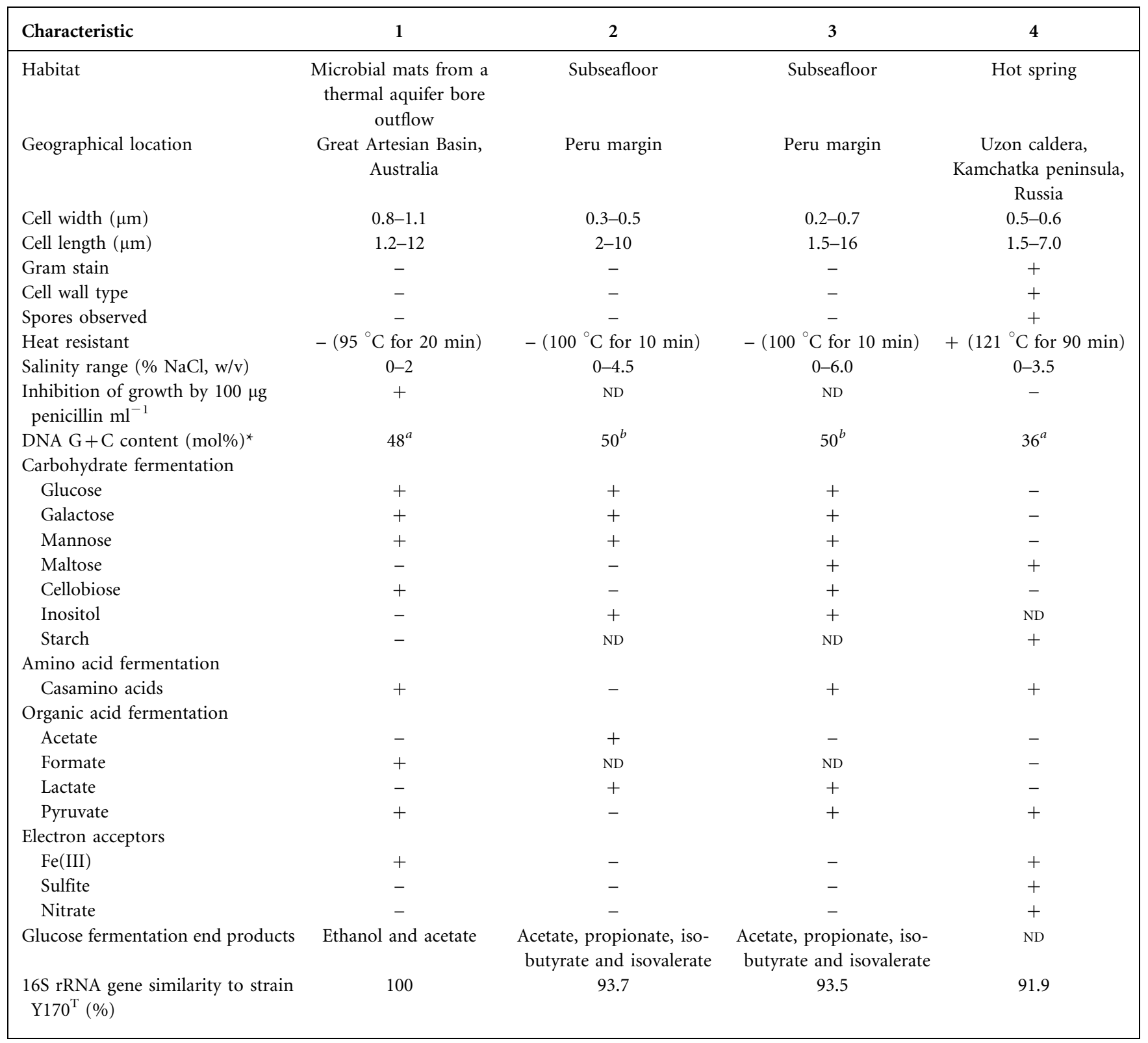

${ }^{\star}$ Determined by using: $a$, the thermal denaturation method; $b$, HPLC.

content, and its ability to utilize cellobiose and formate, but not maltose or starch.

Based on the phenotypic differences and the phylogenetic distance separating strain $\mathrm{Y}_{170^{\mathrm{T}}}$ from other members of the family Syntrophomonadaceae, we propose a new genus and novel species with the name Fervidicola ferrireducens gen. nov., sp. nov., to accommodate this newly described strain.

\section{Description of Fervidicola gen. nov.}

Fervidicola [Fer.vi.di'co.la. L. adj. fervidus glowing, burning; L. suff. - cola (from L. masc. or fem. n. incola) inhabitant, dweller; N.L. masc. n. Fervidicola inhabitant of thermal waters, a thermophilic bacterium].

Cells are strictly anaerobic, slightly curved rods. Gramreaction is negative. Cells possess peritrichous flagella. No spores are produced. $\mathrm{Fe}(\mathrm{III}), \mathrm{Mn}(\mathrm{IV})$, thiosulfate and 
elemental sulfur are used as electron acceptors. 16S rRNA gene analysis indicates that the genus is a member of the family Syntrophomonadaceae, most closely related to members of the genus Thermosediminibacter with a mean similarity of $93.5 \%$. The type species is Fervidicola ferrireducens.

\section{Description of Fervidicola ferrireducens sp. nov.}

Fervidicola ferrireducens [fer.ri.re.du'cens. L. n. ferrum iron; L. part. adj. reducens leading back, bringing back and in chemistry converting to a different oxidation state; N.L. part. adj. ferrireducens reducing $\mathrm{Fe}(\mathrm{III})$ to $\mathrm{Fe}(\mathrm{II})]$.

Exhibits the following properties in addition to those given in the genus description. Cells are $1.2-12 \times 0.8-1.1 \mu \mathrm{m}$. Growth occurs between 55 and $80{ }^{\circ} \mathrm{C}$ (optimum temperature, $70{ }^{\circ} \mathrm{C}$ ) and $\mathrm{pH} 5$ to 9 (optimum, pH 7.0). Grows on yeast extract as a sole carbon source but not on tryptone. Yeast extract is required for growth on tryptone, peptone, fructose, glucose, galactose, cellobiose, mannose, sucrose, xylose, mannitol, formate, pyruvate, Casamino acids and threonine. No growth occurs with arabinose, lactose, maltose, raffinose, chitin, xylan, pectin, starch, acetate, benzoate, lactate, propionate, succinate, myo-inositol, ethanol, glycerol, amyl media, aspartate, leucine, glutamate, alanine, arginine, serine or glycine. $\mathrm{Fe}(\mathrm{III}), \mathrm{Mn}(\mathrm{IV})$, thiosulfate and elemental sulfur serve as electron acceptors, but not sulfate, sulfite, nitrate or nitrite. Fe(III) is reduced in the presence of yeast extract, tryptone, peptone and Casamino acids, but not chitin, xylan, pectin, formate, starch, pyruvate, acetate, benzoate, threonine, lactate, propionate, succinate, inositol, ethanol, glycerol, mannitol, aspartate, leucine, glutamate, alanine, arginine, serine, glycine or $\mathrm{H}_{2}$ and $\mathrm{CO}_{2}$. Sensitive to streptomycin, tetracycline, penicillin, ampicillin and chloramphenicol. Does not grow in $\mathrm{NaCl}$ concentrations greater than $2 \%$. The $\mathrm{G}+\mathrm{C}$ content of the genomic DNA of the type strain is $48 \pm 1 \mathrm{~mol} \%$. Phylogenetically related to members of the genus Thermosediminibacter with a mean $16 \mathrm{~S}$ rRNA gene similarity of $93.5 \%$.

The type strain, $\mathrm{Y}_{170^{\mathrm{T}}} \quad\left(=\mathrm{KCTC} \quad 5610^{\mathrm{T}}=\mathrm{JCM}\right.$ $15106^{\mathrm{T}}=$ DSM $21121^{\mathrm{T}}$ ), was isolated from a microbial mat sample from the outflow of a GAB bore (the New Lorne bore) in Queensland, Australia.

\section{Acknowledgements}

We would like to thank Professor Jean Euzéby for assistance with the Latin nomenclature and Dr Debbie Stenzel for assistance with electron microscopy studies. C. O. is a holder of Griffith University's Australian Postgraduate Research Award (APRA).

\section{References}

Altschul, S. F., Madden, T. L., Schäffer, A. A., Zhang, J., Zhang, Z., Miller, W. \& Lipman, D. J. (1997). Gapped BLAST and PSI-BLAST: a new generation of protein database search programs. Nucleic Acids Res 25, 3389-3402.
Andrews, K. T. \& Patel, B. K. C. (1996). Fervidobacterium gondwanense sp. nov., a new thermophilic anaerobic bacterium isolated from nonvolcanically heated geothermal waters of the Great Artesian Basin of Australia. Int J Syst Bacteriol 46, 265-269.

Brock, T. D. \& Freeze, H. (1969). Thermus aquaticus gen. nov., a nonsporulating extreme thermophile. J Bacteriol 98, 289-297.

Chrisotomos, S., Patel, B. K. C., Dwivedi, P. P. \& Denman, S. E. (1996). Calormator indicus sp. nov., a new thermophilic anaerobic bacterium isolated from the deep-seated nonvolcanically heated waters of an Indian artesian aquifer. Int J Syst Bacteriol 46, 497-501.

Cole, J. R., Chai, B., Farris, R. J., Wang, Q., Kulam, S. A., McGarrell, D. M., Garrity, G. M. \& Tiedje, J. M. (2005). The Ribosomal Database Project (RDP-II): sequences and tools for high-throughput rRNA analysis. Nucleic Acids Res 33, D294-D296.

Felsenstein, J. (1985). Confidence limits on phylogenies: an approach using the bootstrap. Evolution 39, 783-791.

Habermahl, M. A. (1980). The Great Artesian Basin, Australia. BMR J Aust Geol Geophys 5, 9-38.

Hall, T. A. (1999). BioEdit: a user-friendly biological sequence alignment editor and analysis program for Windows 95/98/NT. Nucleic Acids Symp Ser 41, 95-98.

Jukes, T. H. \& Cantor, C. R. (1969). Evolution of protein molecules. In Mammalian Protein Metabolism, pp. 21-123. Edited by H. H. Munro. New York: Academic Press.

Kanso, S. \& Patel, B. K. C. (2003). Microvirga subterranea gen. nov., sp nov., a moderate thermophile from a deep subsurface Australian thermal aquifer. Int J Syst Evol Microbiol 53, 401-406.

Kanso, S., Greene, A. C. \& Patel, B. K. C. (2002). Bacillus subterraneus sp. nov., an iron- and manganese-reducing bacterium from a deep subsurface Australian thermal aquifer. Int J Syst Evol Microbiol 52, 869-874.

Kashefi, K., Holmes, D. E., Baross, J. A. \& Lovley, D. R. (2003). Thermophily in the Geobacteraceae: Geothermobacter ehrlichii gen. nov., sp. nov., a novel thermophilic member of the Geobacteraceae from the "Bag City" hydrothermal vent. Appl Environ Microbiol 69, 2985-2993.

Lee, Y. J., Wagner, I. D., Brice, M. E., Kevbrin, V. V., Mills, G. L., Romanek, C. S. \& Wiegel, J. (2005). Thermosediminibacter oceani gen. nov., sp. nov. and Thermosediminibacter litoriperuensis sp. nov., new anaerobic thermophilic bacteria isolated from Peru Margin. Extremophiles 9, 375-383.

Love, C. A., Patel, B. K. C., Nichols, P. D. \& Stackebrandt, E. (1993). Desulfotomaculum australicum, sp. nov., a thermophilic sulfatereducing bacterium isolated from the Great Artesian Basin of Australia. Syst Appl Microbiol 16, 244-251.

Lovley, D. R. (1997). Microbial Fe(III) reduction in subsurface environments. FEMS Microbiol Rev 20, 305-313.

Lovley, D. R. \& Phillips, E. J. P. (1986). Organic matter mineralization with reduction of ferric iron in anaerobic sediments. Appl Environ Microbiol 51, 683-689.

Lovley, D. R. \& Phillips, E. J. P. (1988). Novel mode of microbial energy metabolism: organic carbon oxidation coupled to dissimilatory reduction of iron or manganese. Appl Environ Microbiol 54, 1472-1480.

Marmur, J. (1961). A procedure for the isolation of deoxyribonucleic acid from microorganisms. J Mol Biol 3, 208-218.

Marmur, J. \& Doty, P. (1962). Determination of the base composition of deoxyribonucleic acid from its thermal denaturation temperature. $J$ Mol Biol 5, 109-118.

Patel, B. K. C., Morgan, H. W. \& Daniel, R. M. (1985a). A simple and efficient method for preparing and dispensing anaerobic media. Biotechnol Lett 7, 277-278. 
Patel, B. K. C., Morgan, H. W. \& Daniel, R. M. (1985b). Fervidobacterium nodosum gen. nov., sp. nov., a new chemoorganotrophic, caldoactive, anaerobic bacterium. Arch Microbiol 141, 63-69.

Ramamoorthy, S., Sass, H., Langner, H., Schumann, P., Kroppenstedt, R. M., Spring, S., Overmann, J. \& Rosenzweig, R. F. (2006). Desulfosporosinus lacus sp. nov., a sulfate-reducing bacterium isolated from pristine freshwater lake sediments. Int J Syst Evol Microbiol 56, 2729-2736.

Redburn, A. C. \& Patel, B. K. C. (1994). Desulfovibrio longreachii sp. nov., a sulfate-reducing bacterium isolated from the Great Artesian Basin of Australia. FEMS Microbiol Lett 115, 33-38.

Saitou, N. \& Nei, M. (1987). The neighbor-joining method: a new method for reconstructing phylogenetic trees. Mol Biol Evol 4, 406425.

Sorensen, J. (1982). Reduction of ferric iron in anaerobic, marine sediment and interaction with reduction of nitrate and sulfate. Appl Environ Microbiol 43, 319-324.

Spanevello, M. D. (2001). The phylogeny of prokaryotes associated with Australia's Great Artesian Basin. PhD thesis, School of Biomolecular and Physical Science, Griffith University, Brisbane, Australia.

Spanevello, M. D., Yamamoto, H. \& Patel, B. K. C. (2002). Thermaerobacter subterraneus sp. nov., a novel aerobic bacterium from the Great Artesian Basin of Australia, and emendation of the genus Thermaerobacter. Int J Syst Evol Microbiol 52, 795-800.

Spratt, H. G., Jr, Siekmann, E. C. \& Hodson, R. E. (1994). Microbial manganese oxidation in saltmarsh surface sediments using a leuco crystal violet manganese oxide detection technique. Estuar Coast Shelf Sci 38, 91-112.

Van de Peer, Y., Jansen, J., De Rijk, P. \& De Wachter, P. (1997). Database on the structure of small ribosomal subunit RNA. Nucleic Acids Res 25, 111-116.

Vargas, M., Kashefi, K., Blunt-Harris, E. L. \& Lovley, D. R. (1998). Microbiological evidence for Fe(III) reduction on early Earth. Nature 395, 65-67.

Wolin, E. A., Wolin, M. J. \& Wolfe, R. S. (1963). Formation of methane by bacterial extracts. J Biol Chem 238, 2882-2886.

Zavarzina, D. G., Tourova, T. P., Kuznetsov, B. B., BonchOsomolovskaya, E. A. \& Slobodkin, A. I. (2002). Thermovenabulum ferriorganovorum gen. nov., sp. nov., a novel thermophilic, anaerobic, endospore-forming bacterium. Int J Syst Evol Microbiol 52, 17371743 .

Zeikus, J. G., Hegge, P. W. \& Anderson, M. A. (1979). Thermoanaerobium brockii gen. nov. and sp. nov., a new chemoorganotrophic, caldoactive, anaerobic bacterium. Arch Microbiol 122, 41-48. 